\title{
Grazing by Prymnesium parvum on small planktonic diatoms
}

\author{
Mercedes Martin-Cereceda ${ }^{1, *}$, Gianfranco Novarino ${ }^{1}$, Jeremy R. Young ${ }^{2}$ \\ ${ }^{1}$ Department of Zoology, and ${ }^{2}$ Department of Palaeontology, The Natural History Museum, Cromwell Road, London SW7 5BD, UK
}

\begin{abstract}
This is the first qualitative and quantitative evidence showing that the marine mixotrophic flagellate Prymnesium parvum (Prymnesiida = Prymnesiophyceae p.p.) is able to graze on small $(5 \mu \mathrm{m})$ planktonic diatoms of the genera Minidiscus and Thalassiosira. Flagellate grazing and diatom species preferences were determined quantitatively in monoxenic batch cultures under nutrient depletion. Video microscopy coupled with digital film was used to visualise the ingestion process. Prey-switching was also investigated using bacteria as an alternative prey and the results were compared with flagellate growth dynamics in the absence of any prey. P. parvum started to graze on diatom cells about 5 min after the diatoms were introduced into the flagellate culture flasks. A reduction of about two-thirds of the initial diatom population occurred in both diatom taxa during the first $2 \mathrm{~h}$ of contact in flasks without bacteria. High interim grazing rates occurred during the first $8 \mathrm{~h}\left(0.30\right.$ diatom flagellate ${ }^{-1} \mathrm{~h}^{-1}$ for $M$. trioculatus and 0.74 diatom flagellate ${ }^{-1} \mathrm{~h}^{-1}$ for Thalassiosira sp.); when bacteria were added, prey-switching (from diatom cells to bacteria) was observed in the $M$. trioculatus experiment. Grazing rates on both diatom species for the duration of the experiment $(144 \mathrm{~h})$ were not statistically different $\left(0.017\right.$ diatom flagellate $\left.{ }^{-1} \mathrm{~h}^{-1}\right)$; when bacteria were added these rates decreased (0.003 diatom flagellate ${ }^{-1} \mathrm{~h}^{-1}$ for Minidiscus trioculatus and 0.002 diatom flagellate ${ }^{-1}$ $\mathrm{h}^{-1}$ for Thalassiosira sp.). Bacterial grazing by $P$. parvum was also similar in both diatom flasks $\left(0.17\right.$ bacteria flagellate $\left.{ }^{-1} \mathrm{~h}^{-1}\right)$. Addition of diatoms to the cultures did not enhance flagellate growth. Diatom capture usually involved the production of a pseudopodium-like structure at the posterior end of flagellate cells. Overall, these results suggest that predation by mixotrophic prymnesiophyte flagellates may be an important factor in regulating populations of nanoplanktonic diatoms in marine environments.
\end{abstract}

KEY WORDS: Diatom grazing - Bacterivory - Marine nanoplankton · Mixotrophic flagellates · Nutrient limitation · Prymnesium parvum

Resale or republication not permitted without written consent of the publisher

\section{INTRODUCTION}

Prymnesiophyte flagellates (Prymnesiida = Prymnesiophyceae p.p.) are an important part of the marine nanophytoplankton, playing a major role in the cycling of organic carbon within the microbial food web (Chavez et al. 1990, Hoepffner \& Haas 1990, Green 1991, Thomsen et al. 1994). A number of these plastidcontaining photosynthetic flagellates fall within the concept of 'mixotrophic' flagellates because they are also capable of phagotrophic nutrition, using various nano- and picoplankton organisms as prey. As with all other mixotrophic protists, the study of the feeding behaviour of mixotrophic prymnesiophytes is of the utmost importance to understanding the functional role of marine nanoplankton in relation to the microbial loop (Azam et al. 1983).

Phagotrophy has been reported in the genera Coccolithus (motile, haploid phase), Chrysochromulina and Prymnesium (Conrad 1941, Parke et al. 1955, 1956, Parke \& Adams 1960, Manton \& Leadbeater 1974, Estep et al. 1986, Jones et al. 1993, 1995, see also Green 1991 and Jones et al. 1994 for reviews). In Prymnesium spp., it has been shown that some species may 
ingest a variety of natural and artificial prey (mostly related to nutrient limitation in the medium): bacteria, unicellular algae, amoebae and fluorescent microspheres (Nygaard \& Tobiesen 1993, Tillmann 1998, Legrand et al. 2001). In particular, the species P. patelliferum (5 to $10 \mu \mathrm{m}$ ) is able to ingest a variety of eukaryotic microorganisms in the size range 5 to $45 \mu \mathrm{m}$ (Tillmann 1998, 2003).

To date, no studies have investigated the ability of mixotrophic prymnesiophytes to graze on small (ca. $5 \mu \mathrm{m}$ ) planktonic diatoms. Diatoms in this size range include the smallest known to science. Among them, species of the centric genera Minidiscus and Thalassiosira are very abundant and widely distributed in the marine plankton (Aké-Castillo et al. 2001), but their ecology is largely unknown because they are easily overlooked, and their taxonomy has received very little attention (Round et al. 1990, Aké-Castillo et al. 2001). At the inception of this study we hypothesised that $5 \mu \mathrm{m}$ species of Minidiscus and Thalassiosira would represent an excellent prey for phagotrophic flagellates because of their size, abundance and ubiquitous distribution. Herein, we present the first laboratorybased evidence that Prymnesium parvum grazes on $M$. trioculatus and Thalassiosira sp., a trophic interaction which has possible implications for the top-down population control of small nanoplankton diatoms in marine environments.

\section{MATERIALS AND METHODS}

Culture strains of the flagellate Prymnesium parvum (Culture Collection of Algae and Protozoa reference CCAP $946 / 6 ; 7$ to $9 \mu \mathrm{m}$ long $\times 4$ to $6 \mu \mathrm{m}$ wide) and the diatoms Minidiscus trioculatus (Provasali-Guillard Center for Culture of Marine Phytoplankton reference CCMP $495 ; 4$ to $8 \mu \mathrm{m}$ long $\times 3$ to $4 \mu \mathrm{m}$ wide) and Thalassiosira sp. (CCMP 1067; 2 to $4 \mu \mathrm{m}$ long $\times 2$ to $4 \mu \mathrm{m}$ wide) were grown in $\mathrm{f} / 2$ medium at 18 to $20^{\circ} \mathrm{C}$ in an incubator using 2 white fluorescent tubes (THORN, Weiss 3500, $8 \mathrm{~W}$ ) under a $16 \mathrm{~h} / 8 \mathrm{~h}$ (light/dark) photoperiod. P. parvum was prepared for the grazing experiments by centrifuging $(2500 \times g, 8 \mathrm{~min})$ late log-phase cultures, then washing 3 times in filtered $(0.2 \mu \mathrm{m}$ pore size) natural seawater, NSW (salinity 32 PSU) (see NSW in Cultured Collection of Algae and Protozoa 1995), and re-suspending in NSW (5 ml final volume) in $25 \mathrm{ml}$ Ehrlenmeyer flasks (3 experimental flasks for each diatom species). NSW was used to ensure nutrient-depleted conditions. A period of $3 \mathrm{~d}$ was allowed for the cells to adapt to the new medium, and then a suspension of diatoms, harvested by centrifuging $(2500 \times g, 17 \mathrm{~min})$ and washed several times with NSW, was added to the flasks. Aliquots were taken from the flasks at fixed times, chemically fixed with acidified Lugol's solution (2.5\% final concentration) and the flagellate and diatoms enumerated using a Neubauer haemocytometer. Grazing experiments lasted $144 \mathrm{~h}$. Control flasks in NSW were prepared for both diatoms and the flagellate.

As a rule, initial concentrations were adjusted to approximately $1.5 \times 10^{6} \mathrm{cells} \mathrm{ml}^{-1}$ for both diatoms, and $1.0 \times 10^{6}$ cells ml $^{-1}$ for Prymnesium parvum (prey: predator ratio of 3:2). A growth dynamics experiment on $P$. parvum in the absence of prey was carried out separately at an initial concentration of $2.0 \times 10^{6}$ cells $\mathrm{ml}^{-1}$.

To investigate prey-switching in the presence of bacteria, parallel experiments were carried out in which a surplus of Vibrio natriegens $\left(0.90 \pm 0.30 \mu \mathrm{m}^{3}\right.$; Colección Española de Cultivos Tipo [CECT] Strain No. 526) was also added to the flagellate culture flasks. Bacteria were grown initially in nutrient agar (Oxoid) plates, harvested from the plates with a sterile loop, and vortex-homogenised in filtered $(0.2 \mu \mathrm{m}$ pore size $)$ NSW. A sample of this suspension was taken to determine bacterial concentration by the acridine orange technique (Hobbie et al. 1977). Subsequently, a fixed volume of the stock suspension was added to all flasks to give a final bacterial concentration of about $8 \times 10^{8}$ bacteria $\mathrm{ml}^{-1}$. Bacterial concentrations in the experiment flasks were determined by collecting a subsample, fixing with glutaraldehyde $(2.5 \%$ final concentration), and enumerating by the method of Hobbie et al. (1977). The bacteria:diatom ratio was adjusted at about $5 \times 10^{2}: 1$ in both the Minidiscus and Thalassiosira flasks. Flagellates and diatoms were counted as described above. Control flasks concentration NSW plus bacteria were prepared for each protist experiment, as well as a NSW control containing bacteria only. During the experiment, the flasks were gently shaken a few times daily in order to avoid the formation of diatom aggregates.

Grazing rates were measured as the reduction in prey (diatoms and bacteria) per unit time and predator (flagellate) and corrected based on the variation in the diatom population densities in the control flasks. The rates were derived from the formula $g=(p t-p o)(f t-f o)^{-1}$ $t^{-1}$, where $g$ is grazing rate $\left(\mathrm{h}^{-1}\right), p t$ and $p o$ are the final and initial prey concentrations (cells $\mathrm{ml}^{-1}$ ) respectively, $t$ is the time interval, and $f t$ and $f o$ are the final and initial flagellate concentrations (cells ml ${ }^{-1}$ ) respectively.

For Prymnesium parvum, an additional experiment to determine its growth dynamics in the absence of prey was carried out by replacing the diatoms or bacteria with a fixed volume of fresh $\mathrm{f} / 2$ medium added to the cultures after the $3 \mathrm{~d}$ of acclimatisation in NSW. Samples were processed and enumerated as described above. 
Live observations of the grazing process were made in $5.5 \mathrm{~cm}$ diameter Petri dishes using a Leica DM IRB inverted microscope at 630 magnification, and recorded with a JVC TK-C1381 CCD video camera on a Sony U-Matic SP recorder. Videotape clips were converted to digital format using a Macintosh computer fitted with a Radius VideoVision digitizer. Single digital frames were extracted from the digital film clips using Adobe Premiere.

In order to test the statistical significance of the differences between rates, Wilcoxon-Mann-Whitney and Kruskal-Wallis non-parametric tests were applied. A Student's t-test was also used for comparing the
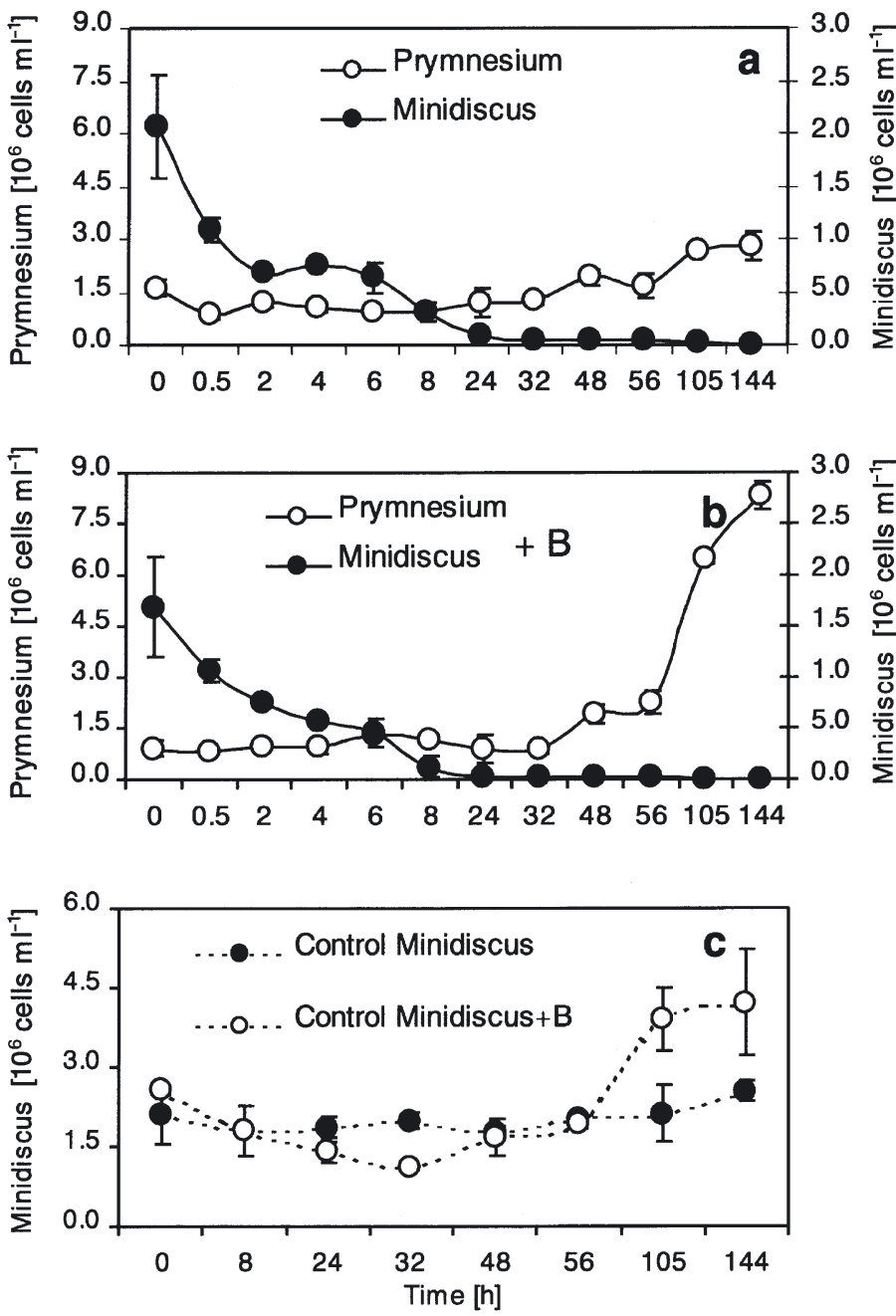

Fig. 1. (a) Prymnesium parvum and Minidiscus trioculatus. Variation in populations during $144 \mathrm{~h}$ experimental period, showing grazing effect of flagellate; (b) variation in populations in presence of bacterium Vibrio natriegens, showing grazing effect of flagellate; (c) variation in $M$. trioculatus population in control flasks; Control Minidiscus $=M$. trioculatus in natural seawater $(\mathrm{NSW}) ;$ Control Minidiscus $+\mathrm{B}=$ M. trioculatus in NSW plus bacteria. Data points represent average values, error bars $\pm \operatorname{SD}(n=9)$ grazing rates of Prymnesium on bacteria after checking for normality of data and equality of variances. All analyses were carried out with Statgraphics Plus 5.1.

\section{RESULTS}

\section{Diatom and bacteria grazing experiments}

The growth curves and trophodynamics of Prymnesium parvum on the diatoms Minidiscus trioculatus and Thalassiosira sp. are illustrated in Figs. 1 \& 2. A reduction of about two-thirds of the initial diatom
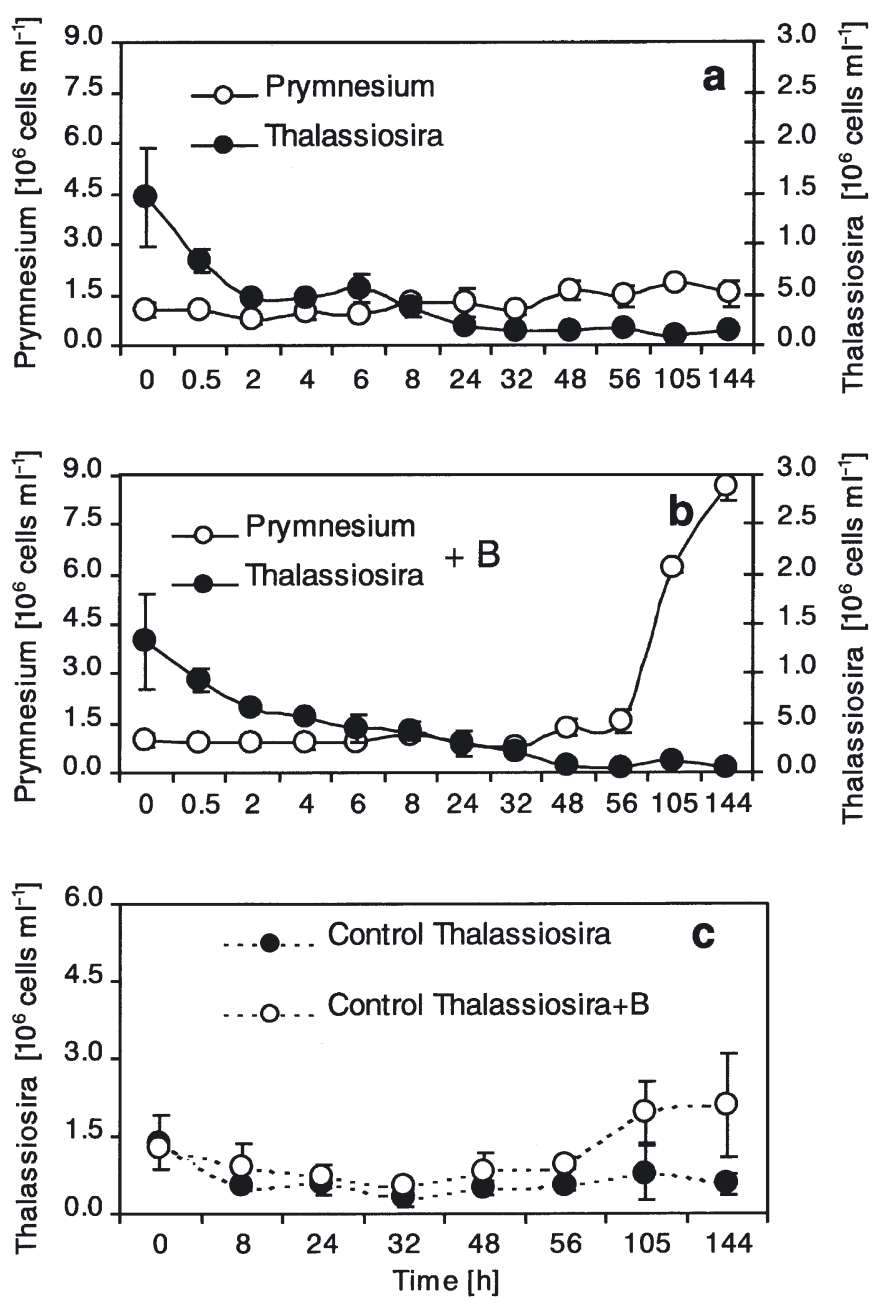

Fig. 2. (a) Prymnesium parvum and Thalassiosira sp. Variation in populations during $144 \mathrm{~h}$ experimental period, showing grazing effect of flagellate; (b) variation in populations in presence of bacterium Vibrio natriegens, showing grazing effect of flagellate; (c) variation in Thalassiosira sp. population in control flasks; Control Thalassiosira = Thalassiosira sp. in NSW; Control Thalassiosira $+\mathrm{B}=$ Thalassiosira sp. in NSW plus bacteria. Data points represent average values, error bars $\pm \operatorname{SD}(n=9)$ 
population was observed in both diatom taxa during the first $2 \mathrm{~h}$ of contact in flasks without bacteria (Figs. 1a \& 2a).

Interim grazing rates during the first $8 \mathrm{~h}$ were high, 0.30 diatom flagellate ${ }^{-1} \mathrm{~h}^{-1}$ for Minidiscus trioculatus and 0.74 diatom flagellate ${ }^{-1} \mathrm{~h}^{-1}$ for Thalassiosira sp. (Fig. 3). When bacteria were added to the flagellate culture flasks, grazing on diatoms was also active, but the interim grazing rates during the first $8 \mathrm{~h}$ decreased, which may indicate prey-switching (Fig. 3). However, the Wilcoxon-Mann-Whitney test did not show a statistically significant difference between the whole set of interim grazing rates of $M$. trioculatus ( $\mathrm{W}=382.5$, $\mathrm{p}=0.17$ ) or Thalassiosira sp. ( $\mathrm{W}=577.0, \mathrm{p}=0.17)$ in the presence or absence of bacteria. When the interim rates were treated separately, there was a significant difference between the grazing rates on $M$. trioculatus with and without bacteria ( $\mathrm{W}=0.0, \mathrm{p}=0.03$ ) during the first $8 \mathrm{~h}$. This indicates that prey-switching (from diatom cells to bacteria) may have occurred during the first $8 \mathrm{~h}$ in the flasks containing $M$. trioculatus. From $24 \mathrm{~h}$ onwards for $M$. trioculatus and $32 \mathrm{~h}$ onwards for Thalassiosira sp., the consumption of diatoms was roughly equivalent in the presence and in absence of bacteria (Fig. 3).
Grazing rates on either diatom species for the duration of the experiment $(144 \mathrm{~h})$ were not statistically different $\left(0.017\right.$ diatom flagellate ${ }^{-1} \mathrm{~h}^{-1}$ ) (Wilcoxon-MannWhitney test $\mathrm{W}=3.0, \mathrm{p}=0.172$ ) in either case. These rates decreased (0.003 diatom flagellate ${ }^{-1} \mathrm{~h}^{-1}$ for Minidiscus trioculatus and 0.002 diatom flagellate $\mathrm{e}^{-1} \mathrm{~h}^{-1}$ for Thalassiosira sp.) when bacteria were added, but no statistical differences between these values were observed ( $\mathrm{W}=4.0, \mathrm{p}=0.31$ ). In the case of $M$. trioculatus there was a statistically significant difference between the grazing rates in the flasks with and without bacteria ( $\mathrm{W}=16, \mathrm{p}=0.029)$, but not in the case of Thalassiosira sp. ( $\mathrm{W}=8.5, \mathrm{p}=0.99$ ).

To quantify the effect of Prymnesium parvum on the bacterial population, the bacterial concentration was also determined in the experimental flasks (Fig. 4). There was a $31 \%$ reduction in the initial bacterial population at the end of the experiment $(144 \mathrm{~h})$ for both diatoms (Fig 4a), while in the control flask for bacteria (Fig. 4 b) there was a reduction of $9 \%$. This means that the flagellates were able to consume approximately $22 \%$ of the bacterial population in $144 \mathrm{~h}$. Grazing rates on bacteria were 0.17 bacteria flagellate ${ }^{-1} \mathrm{~h}^{-1}$ for both diatoms flasks, and were not statistically different (Student's $t$-test $=0.008, \mathrm{p}=0.99$ ).
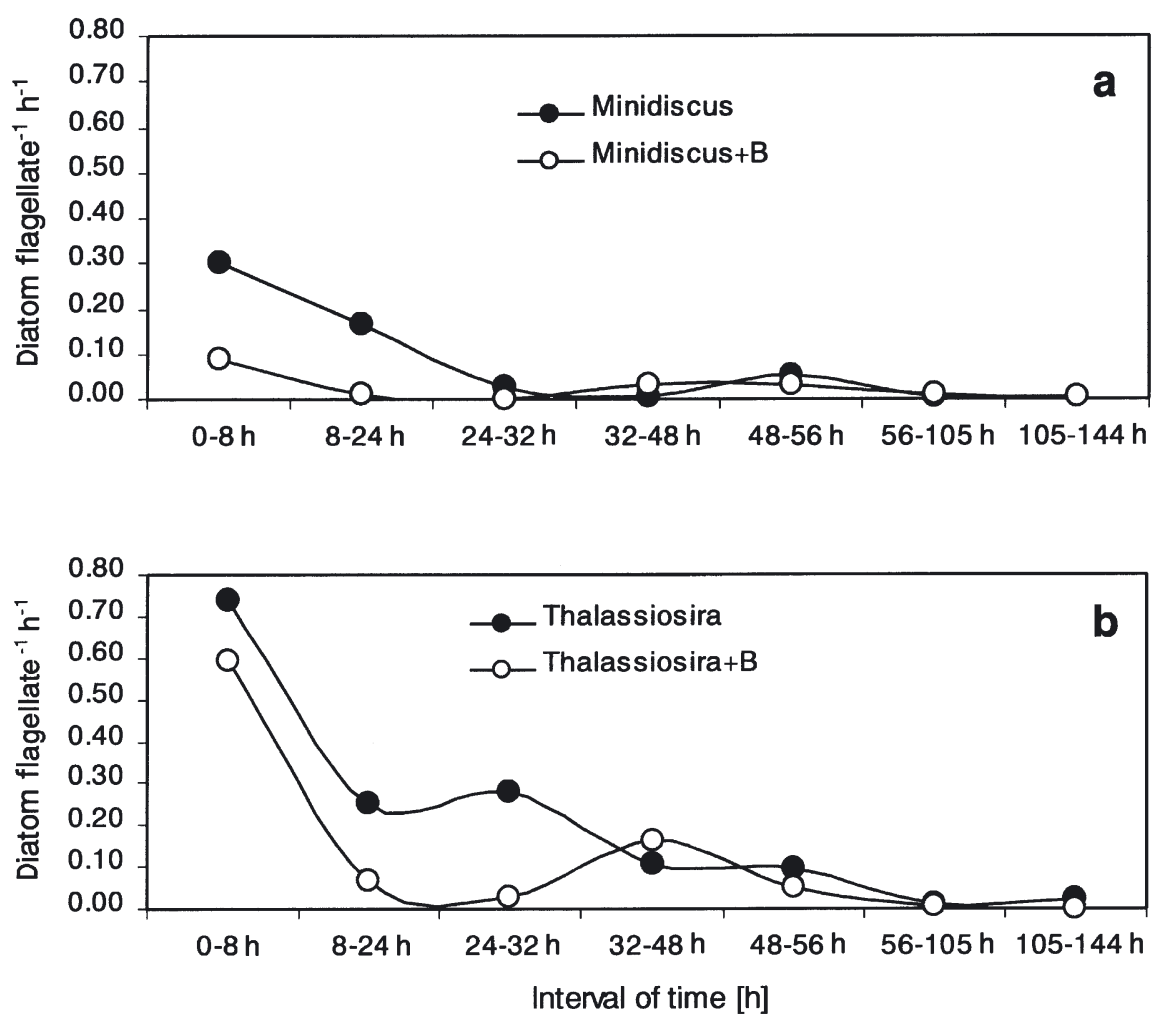

Fig. 3. Prymnesium parvum. Grazing rates (diatom flagellate $\mathrm{e}^{-1} \mathrm{~h}^{-1}$ ) at intervals, during experimental period on (a) Minidiscus trioculatus with and without bacteria, and (b) Thalassiosira sp. with and without bacteria

\section{Flagellate growth rates}

A strong increase in flagellate populations occurred when bacteria were added to the experimental flasks (Figs. 1b \& 2b). Flagellate growth rates were $0.016 \mathrm{~h}^{-1}$ in Minidiscus trioculatus flasks and $0.015 \mathrm{~h}^{-1}$ in Thalassiosira sp. flasks in the presence of bacteria, with the flagellate considerably increasing its population $56 \mathrm{~h}$ after bacterial addition. A growth rate of $0.016 \mathrm{~h}^{-1}$ was also observed in the flagellate control flask with bacteria (flagellate plus bacteria in NSW; Fig. 5). These rates were not statistically different (Kruskal-Wallis 1-way ANOVA by ranks: $H=0.85$ and $\mathrm{p}=$ 0.65 ) suggesting that the presence of diatoms did not influence the production of flagellate biomass.

Growth dynamics of Prymnesium parvum in the presence of prey was compared to that occurring when only $\mathrm{f} / 2$ medium was supplied to the flagellate cultures in NSW (Fig. 6). The flagellate growth rate $\left(0.006 \mathrm{~h}^{-1}\right)$ was significantly lower than that observed 

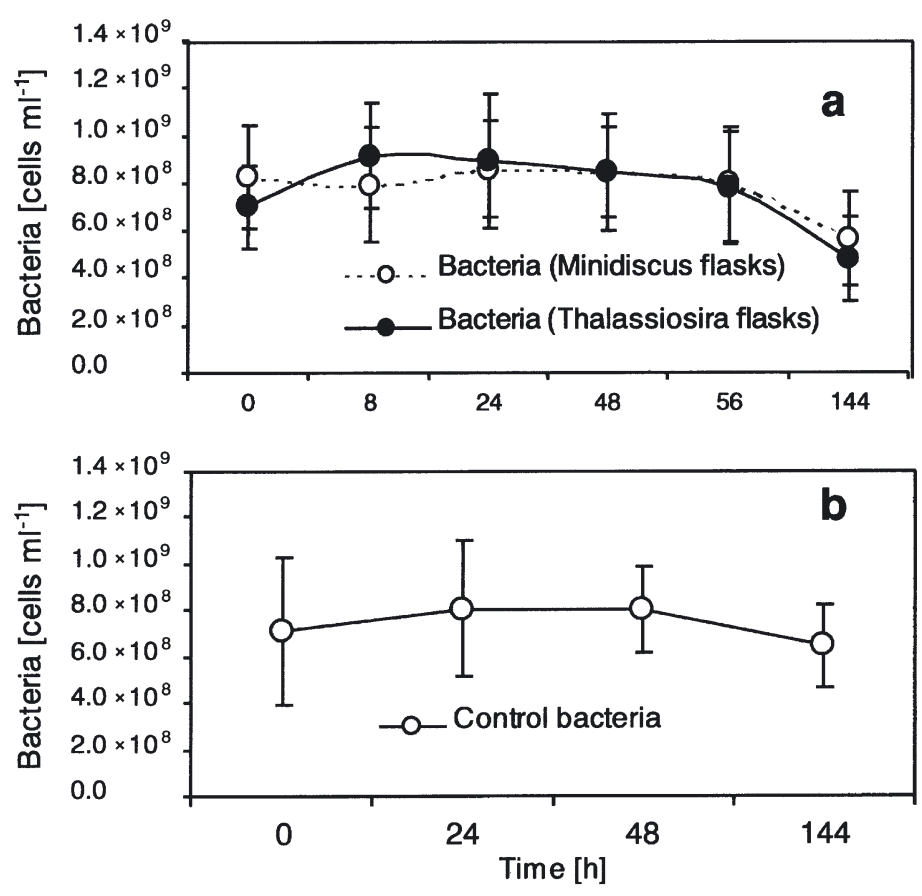

Fig. 4. (a) Vibrio natriegens. Variation during $144 \mathrm{~h}$ experimental period in bacterial populations in experimental flasks containing Minidiscus trioculatus or Thalassiosira sp.; (b) variation in bacterial population in control flask (bacteria only in NSW). Data points represent average values, error bars $\pm \mathrm{SD}(\mathrm{n}=9)$

when bacteria were added to the cultures (KruskalWallis $H=8.16, \mathrm{p}=0.017$ ).

Table 1 summarises the experimental conditions used to determine the grazing rates of Prymnesium parvum, its growth rates and its effect on both diatom species and bacteria.

\section{Control experiments}

In the case of Minidiscus trioculatus, the NSW control (Fig. 1c) showed that its population increased by $18 \%$ from the beginning to the end of the experiment when bacteria were absent, and by $40 \%$ when they were present. This indicates that the population decrease of $M$. trioculatus in the flagellate culture flasks was due entirely to grazing by the flagellate. Control flasks of Thalassiosira sp. in NSW (Fig. 2c) revealed that the initial population was reduced by approximately $40 \%$ at the end of the experiment, suggesting that a proportion of the reduction observed in the flagellate culture flasks may have resulted from the inability of the diatom to survive in filtered seawater. In contrast, in the Thalassiosira sp. control flask in NSW plus bacteria, a $40 \%$ increase in the initial population was observed, resulting perhaps from the availability of bacterial products promoting diatom growth.

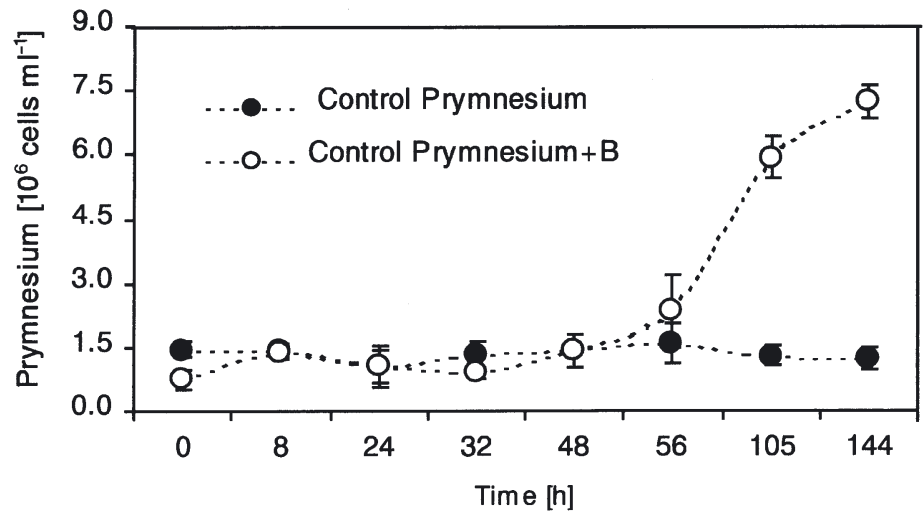

Fig. 5. Prymnesium parvum. Variation during $144 \mathrm{~h}$ experimental period in population in control flasks. Control Prymnesium: P. parvum in NSW; Control Prymnesium + B: P. parvum in NSW plus bacteria.

Data points represent average values, error bars $\pm \mathrm{SD}(\mathrm{n}=9)$

\section{Microscope-monitored experiments}

The ingestion of the diatoms occurred very rapidly. Flagellates started to feed on diatom cells about $5 \mathrm{~min}$ after these were added to the flagellate cultures. The first reaction of Prymnesium parvum to the presence of diatoms was to move into close contact with them (Fig. 7a). After another 1 to $2 \mathrm{~min}$, the diatoms were displaced to the posterior end of the flagellate cell, which produced a pseudopodium-like structure that surrounded the diatom cell and then ingested it whole (Fig. 7b,e). We did not observe any involvement of the flagella or the haptonema in the ingestion process. While feeding, the flagellates reduced their movement and sometimes formed aggregates of varying size with the diatom cells. Cells of $P$. parvum were observed that contained more than 1 ingested diatom cell (Fig.7f).

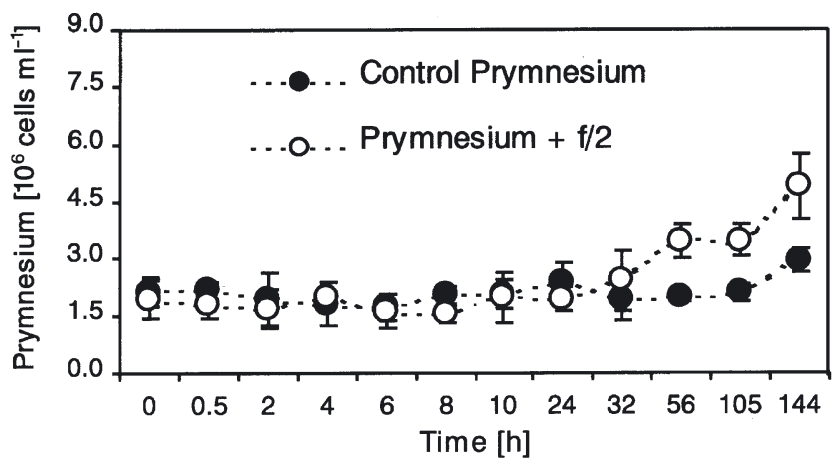

Fig. 6. Prymnesium parvum. Growth dynamics during $144 \mathrm{~h}$ experimental period in absence of prey. Control Prymnesium: P. parvum in NSW; Prymnesium + f/2: P. parvum in NSW with addition of $\mathrm{f} / 2$ medium. Data points represent average values, error bars $\pm \mathrm{SD}(\mathrm{n}=9)$ 
Table 1. Experimental conditions examining effects of grazing of Prymnesium parvum on diatoms Minidiscus trioculatus and Thalassiosira sp. and the bacterium Vibrio natriegens. Grazing rates for whole period of the experiment (144 h) are also shown; see Fig. 3 for grazing rates at intervals during experiment

\begin{tabular}{|c|c|c|c|c|c|c|}
\hline \multirow[t]{2}{*}{ Flasks } & \multicolumn{3}{|c|}{$\longrightarrow$ Initial density (cells $\mathrm{ml}^{-1}$ ) } & \multirow{2}{*}{$\begin{array}{c}P . \text { parvum } \\
\text { growth rate } \\
\qquad\left(\mathrm{h}^{-1}\right)\end{array}$} & \multicolumn{2}{|c|}{$\begin{array}{l}\text { Grazing rate } \\
\text { (flagellate } \mathrm{h}^{-1} \text { ) }\end{array}$} \\
\hline & Diatom & Bacteria & P. parvum & & Diatom & Bacteria \\
\hline \multicolumn{7}{|l|}{ Experimental } \\
\hline Thalassiosira sp. & $1.5 \times 10^{6} \pm 0$ & - & $1.1 \times 10^{6} \pm 3.2 \times 10^{5}$ & 0.002 & 0.017 & - \\
\hline Thalassiosira sp. + bacteria & $1.5 \times 10^{6} \pm 5.5 \times 10^{4}$ & $7.4 \times 10^{8} \pm 1.7 \times 10^{8}$ & $1.0 \times 10^{6} \pm 1.3 \times 10^{5}$ & 0.015 & 0.002 & 0.17 \\
\hline Minidiscus trioculatus & $2.0 \times 10^{6} \pm 3.2 \times 10^{5}$ & - & $1.6 \times 10^{6} \pm 1.3 \times 10^{5}$ & 0.004 & 0.017 & - \\
\hline M. trioculatus + bacteria & $1.7 \times 10^{6} \pm 4.8 \times 10^{5}$ & $8.1 \times 10^{8} \pm 2.1 \times 10^{8}$ & $1.0 \times 10^{6} \pm 2.3 \times 10^{5}$ & 0.016 & 0.003 & 0.17 \\
\hline$f / 2$ & - & - & $2.0 \times 10^{6} \pm 5.3 \times 10^{5}$ & 0.006 & - & - \\
\hline \multicolumn{7}{|l|}{ Control } \\
\hline Thalassiosira sp. & $1.4 \times 10^{6} \pm 5.2 \times 10^{5}$ & - & - & - & - & - \\
\hline Thalassiosira sp. + bacteria & $1.3 \times 10^{6} \pm 5.1 \times 10^{5}$ & - & - & - & - & - \\
\hline M. trioculatus & $2.1 \times 10^{6} \pm 3.1 \times 10^{4}$ & - & - & - & - & - \\
\hline M. trioculatus + bacteria & $2.3 \times 10^{6} \pm 2.0 \times 10^{5}$ & - & - & - & - & - \\
\hline P. parvum & - & - & $1.5 \times 10^{6} \pm 1.8 \times 10^{5}$ & 0.001 & - & - \\
\hline P. parvum + bacteria & - & - & $1.0 \times 10^{6} \pm 2.3 \times 10^{5}$ & 0.016 & - & - \\
\hline Bacteria & - & $7.1 \times 10^{8} \pm 3.8 \times 10^{8}$ & - & - & - & - \\
\hline
\end{tabular}
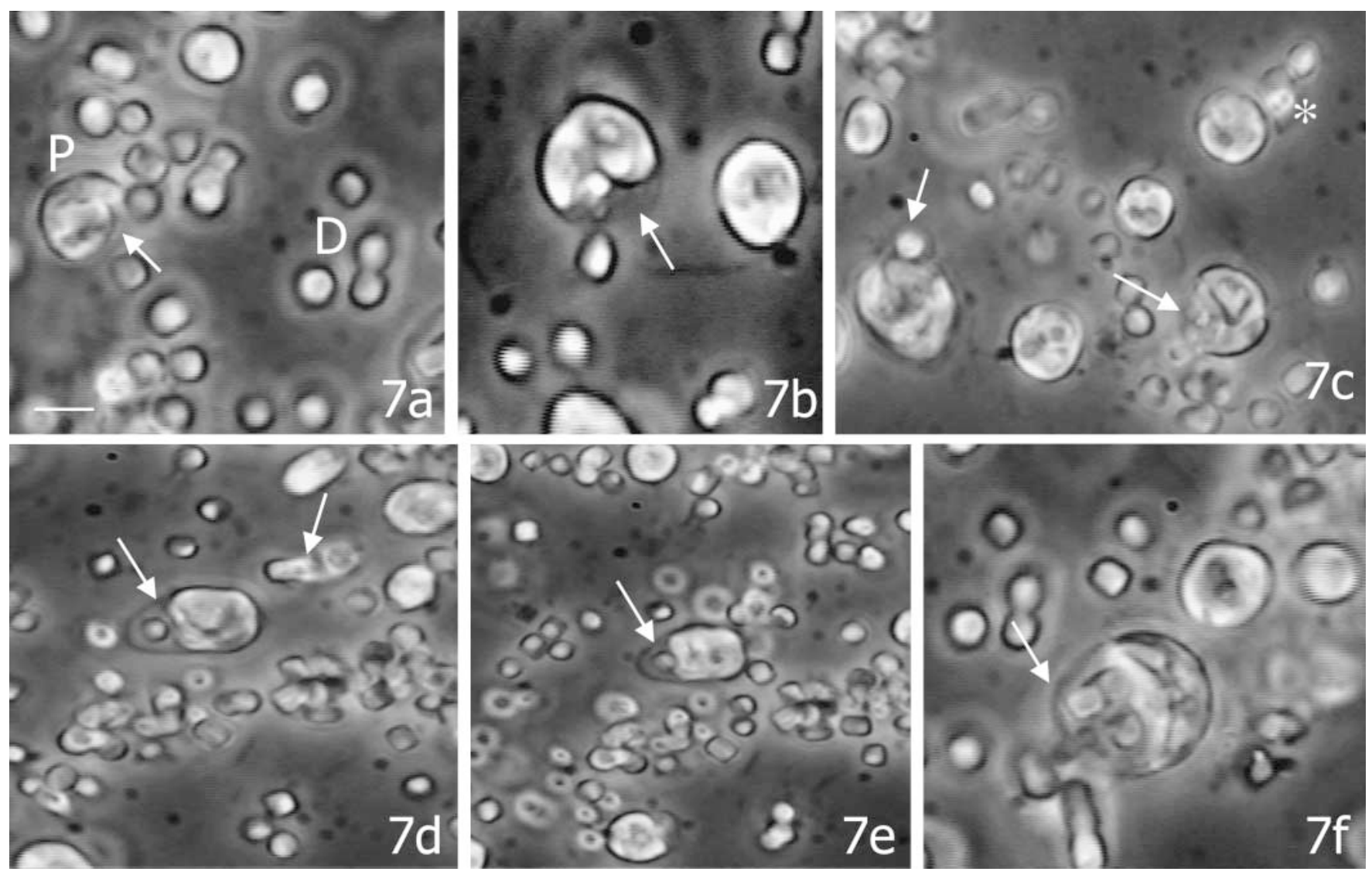

Fig. 7. Prymnesium parvum. Still images extracted from digital video clips, showing flagellate ingesting diatom cells. Scale bar $=5$ um. $(\mathrm{a}, \mathrm{b})$ Initial contact between cells of P. parvum (P) and diatom cells (D) by means of pseudopodium-like structure (arrow) at posterior end of P. parvum. (c) P. parvum cells ingesting cells of Thalassiosira sp., diatoms are being enclosed inside flagellate cells (arrows); note also attachment of some diatoms to a flagellate cell (asterisk). (d,e) Diatoms inside P. parvum cells; note conspicuous posterior hyaline end (arrows) containing the diatoms. (f) P. parvum cell containing 3 diatom cells inside enlarged posterior hyaline end (arrow) 


\section{DISCUSSION}

This study provides quantitative laboratory evidence of grazing by Prymnesium parvum on Minidiscus trioculatus and Thalassiosira sp. Most of the work on particle ingestion in prymnesiophytes is related to Chrysochromulina spp. (Conrad 1941, Parke et al. 1955, 1956, Green 1991, Jones et al. 1993, 1995). Conrad (1941) was the first author to suggest the ingestion of small prey, presumably bacteria, by a species of Prymnesium (P. saltans). Nygaard \& Tobiesen (1993) estimated the grazing rates of $P$. parvum on radio- and fluorescently labelled bacteria, and Tillmann (1998) showed that $P$. patelliferum was able to graze on other prey in addition to bacteria; the fact that diatoms were not ingested was attributed to the external processes and surface properties of silica diatom shells, together with the formation of cell aggregates by the diatoms. Otterstrom \& Snielsen (1940) also concluded that diatoms were not grazed by $P$. parvum. The present study provides the first qualitative and quantitative evidence that $P$. parvum is able to graze on nanoplanktonic diatoms, confirming the observations on other species of nanoflagellates such as the heterotrophic chrysomonad Spumella sp., which is able to feed on the nanoplanktonic diatom Cyclotella glomerata (Von Steinberg 1980), and Paraphysomonas imperforata, which was seen to feed on the large pennate diatom Phaeodactylum tricornotum (Caron et al. 1985, Goldman et al. 1985).

The grazing pressure exercised by Prymnesium parvum on the diatoms studied here is remarkable. Doddema \& Van der Veer (1983) indicated that phagotrophy results in the uptake of particulate organic $\mathrm{N}$ and $\mathrm{P}$ when inorganic nutrients are limited. Nygaard \& Tobiesen (1993) suggested a relationship between lack of orthophosphate and degree of bacterivory in prymnesiophytes. Bacteria are a potential source of iron (as ferrous ion) which is required for growth and physiological processes (Andrews 1998). Bacteria are also a source of $\mathrm{P}$, which they contain in high concentrations (Bartbak \& Thingstad 1985, Andersen et al. 1986). Our results suggest that diatoms may also be a potential source of N, P and possibly even iron; it was recently shown that mixotrophic flagellates do not necessarily require iron to be in dissolved form in order to be able to utilise it (Nodwell \& Price 2001). In the absence of bacteria (considered the prey 'par excellence' under nutrient limiting conditions) the flagellate feeds on diatoms, which seem to satisfy its immediate nutritional requirements. When bacteria are present, $P$. parvum continues to ingest diatoms, but also enlarges its prey repertoire to include bacteria. Grazing rates on diatoms are reduced when bacteria are present, suggesting the possibility of prey-switching. However, the observed differences in grazing rates were not statistically significant except during the first $8 \mathrm{~h}$ of the Minidiscus trioculatus experiment, suggesting that preyswitching (from diatom cells to bacteria) may have occurred.

When both types of prey (diatoms plus bacteria) are present, bacterial consumption in Prymnesium parvum is not very high compared with that of purely heterotrophic flagellates. Kinner et al. (1998) reported grazing (uptake) rates of 0.77 bacteria flagellate $\mathrm{e}^{-1} \mathrm{~h}^{-1}$ for bacteria in the same size class as Vibrio natriegens (see Table 4 in Kinner et al. 1998), while our values are about $4 \frac{1}{2}$ times smaller. However, results may not be directly comparable, since Kinner et al. (1998) estimated grazing rates using a direct method involving fluorescent labelled bacteria (FLB).

The fact that Prymnesium parvum did not show a significant population increase when it fed on the 2 diatoms studied here could perhaps be explained by the fact that diatom ingestion might not necessarily imply their digestion. It has been shown (Boenigk et al. $2001 \mathrm{a}, \mathrm{b})$ that the spectrum of particles ingested by flagellates may differ from that of digested particles, and a concept of selective or differential digestion has been elaborated. However, in our study, it is also possible that digestion of diatoms did occur, but that their nutritional value was insufficient to cause a significant increase in P. parvum populations.

Our results comparing flagellate growth in $f / 2$ medium with that observed in the presence of bacteria suggest that Prymnesium parvum grows better as a mixotroph than as a pure photoautotroph. In mixotrophic prymnesiophytes, it is not known with certainty whether phagotrophy is regulated by the availability of nutrients (or potential prey), or by light intensity (Jones et al. 1993, 1994). In P. parvum, no evidence of darkness-induced phagotrophy has been found (Jochem 1999). In contrast, induced phagotrophy when dissolved organic growth factors (i.e. vitamins) and/or mineral nutrients (i.e. P) are limited or depleted has been demonstrated by Nygaard \& Tobiesen (1993), and can also be inferred here based on the data from the present study. After a period of nutrient limitation, phagotrophically gained compounds (bacteria) could induce $P$. parvum to grow faster than in the presence of organic compounds acquired photosynthetically. In other words, during periods of inorganic nutrient limitation, diatom predation might be a strategy to maintain biomass of $P$. parvum without altering the population size, while bacteria could be excellent short-term promoters of $P$. parvum growth resulting in a rapid population increase.

In terms of Prymnesium parvum prey preference, no significant differences were found between Minidiscus trioculatus and Thalassiosira sp. Prey selection in 
prymnesiophytes has been related to particle size (Jones et al. 1993, 1994), and both diatoms tested in this study are in the same size range. Prey selection by P. patelliferum has been suggested by Tillmann (1998), not on a size basis, since $P$. patelliferum was able to ingest prey larger than itself.

Regarding the ingestion process itself, Prymnesium parvum ingests diatoms much in the same way as $P$. patelliferum, Chrysochromulina kappa and C. ericina ingest other types of prey (Parke et al. 1955, 1956, Tillmann 1998). In some prymnesiophytes, the haptonema plays an important role in prey capture (Kawachi et al. 1991, Inouye \& Kawachi 1994). We have not observed any involvement of the haptonema of $P$. parvum in the ingestion process, in accordance with Tillmann (1998). In Prymnesium spp. the haptonema is short and noncoiling, and this could well prevent its active role in food capture (Green 1991).

From an ecological viewpoint, our study presents the possibility that a high predation pressure of Prymnesium parvum on nanoplankonic diatoms might occur also in nature. Detailed information on the quantitative occurrence of $P$. parvum in natural environments is scarce, analogous to the situation for other unmineralised prymnesiophytes (Thomsen et al. 1994). However, blooms of Prymnesium species, which may have notorious implications for fish kills and environmental quality, are known to occur with cell densities in the approximate range of $10^{7}$ to $10^{11}$ cells $1^{-1}$ (Moestrup 1994). From incidental scanning electron microscope observations during a study of coccolithophores, we noted that Minidiscus trioculatus is a very widespread diatom, occurring in all oceans from sub-arctic to subtropical latitudes, where it is often associated with high abundances of the coccolithophore Emiliania huxleyi. The highest abundances we observed were in a mixed E. huxleyi-M. trioculatus bloom off SW Iceland in July 1999 where $M$. trioculatus cell densities reached to $3.7 \times 10^{6}$ cells $^{-1}$ (M. Hockfield unpubl. data). The factors controlling such diatom population densities are currently unknown.

In the present study, although we cultured the flagellate and diatoms at concentrations roughly 1000 times greater than those reported in natural environments, the predator:prey ratios appeared to be similar to those in nature. Therefore, it is possible that the predation pressure of Prymnesium parvum on small diatoms in nature is similar to that during our study. If this were effectively so, grazing by mixotrophic or heterotrophic nanoflagellates could be a key factor in the regulation of Minidiscus spp. or small-cell Thalassiosira spp. populations in the marine plankton. Topdown regulation of small-cell diatom populations could also result in a lower predation pressure on bacteria, which could have important consequences for the structure and functioning of the microbial food web in pelagic ecosystems. Further work is necessary to investigate this possibility.

Acknowledgements. This study was supported by a Postdoctoral Fellowship from 'Fundacion Ramon Areces' (Convocatoria 2002), Madrid (Spain) to M.M-C. and an MRF grant from The Natural History Museum to G.N. in collaboration with J.R.Y. and Dr. E. J. Cox (Department of Botany, The Natural History Museum). M.M-C. is much indebted to R. A. J. Williams (Department of Zoology, The Natural History Museum) for his critical reading of the manuscript and his valuable advice.

\section{LITERATURE CITED}

Azam F, Fenchel T, Field JG, Meyer-Reil LA, Thingstad F (1983) The ecological role of water-column microbes in the sea. Mar Ecol Prog Ser 10:257-263

Ake-Castillo JA, Hernandez-Becerril DU, Meave del Castillo ME, Bravo-Sierra E (2001) Species of Minidiscus (Bacillariophyceae) in the Mexican Pacific Ocean. Cryptogam Algol 22:101-107

Andersen OK, Goldman JC, Caron DA, Dennet MR (1986) Nutrient cycling in a microflagellate food chain: 3. Phosphorus dynamics. Mar Ecol Prog Ser 31:47-55

Andrews SC (1998) Iron storage in bacteria. Adv Microb Physiol 40:281-351

Bartbak G, Thingstad TF (1985) Phytoplankton-bacteria interaction: an apparent paradox? Analysis of a model system with both competition and commensalism. Mar Ecol Prog Ser 25:23-30

Boenigk J, Matz C, Jurgens K, Arndt H (2001a) The influence of preculture conditions and food quality on the ingestion and digestion process of three species of heterotrophic nanoflagellates. Microb Ecol 42:168-176

Boenigk J, Matz C, Jurgens K, Arndt H (2001b) Confusing selective feeding with differential digestion in bacterivorous nanoflagellates. J Eukaryot Microbiol 48:425-432

Caron DA, Goldman JC, Andersen OK, Dennett MR (1985) Nutrient cycling in a microflagellate food chain: II. Population dynamics and carbon cycling. Mar Ecol Prog Ser 24:243-254

Chavez FP, Buck KR, Barber RT (1990) Phytoplankton taxa in relation to primary production in the equatorial Pacific. Deep-Sea Res 11:1733-1752

Conrad W (1941) Sur les Chrysomonadines à trois fouets. Aperçu synoptique. Bull Mus Natl Hist (Belg) 17:1-16

Culture Collection of Algae and Protozoa (CCAP) (1995) CCAP catalogue of strains. Culture Collection of Algae and Protozoa Publications. Institute of Freshwater Ecology (IFE), Ambleside; available at www.ife.ac.uk/ccap/

Doddema H, Van der Veer J (1983) Ochromonas monicis sp. nov. a particle feeder with bacterial endosymbionts. Cryptogam Algol 4:89-97

Estep KW, Davis PG, Keller MD, Sieburth JM (1986) How important are oceanic algal nanoflagellates in bacterivory? Limnol Oceanogr 31:646-650

Goldman JC, Caron DA, Andersen OK, Dennett MR (1985) Nutrient cycling in a microflagellate food chain: I. Nitrogen dynamics. Mar Ecol Prog Ser 24:231-242

Green JC (1991) Phagotrophy in prymnesiophyte flagellates. In: Patterson DJ, Larsen J (eds) The biology of free-living heterotrophic flagellates. Systematic Association, Claren- 
don Press, Oxford, p 401-414

Hobbie JD, Daley RJ, Jasper S (1977) Use of Nuclepore filters for counting bacteria by fluorescence microscopy. Appl Environ Microbiol 33:1225-1228

Hoepffner N, Haas LW (1990) Electron microscopy of nanoplankton from the North Pacific central gyre. J Phycol 26:421-439

Inouye I, Kawachi M (1994) The haptonema. In: Green JC, Leadbeater BSC (eds) The haptophyte algae, Spec Vol No 51. Systematic Association, Clarendon Press, Oxford, p 73-89

Jochem FJ (1999) Dark survival strategies in marine phytoplankton assessed by cytometric measurement of metabolic activity with fluorescein diacetate. Mar Biol 135: $721-728$

Jones HL, Leadbeater BSC, Green JC (1993) Mixotrophy in marine species of Chrysochromulina (Prymnesiophyceae). Ingestion and digestion of a small green flagellate. J Mar Biol Assoc UK 73:283-296

Jones HL, Leadbeater BSC, Green JC (1994) Mixotrophyic haptophytes. In: Green JC, Leadbeater BSC (eds) The haptophyte algae, Spec Vol No. 51. Systematic Association, Clarendon Press, Oxford, p 247-263

Jones HL, Durjun P, Leadbeater BSC, Green JC (1995) The relationship between photoacclimation and phagotrophy with respect to chlorophyll $a$, carbon and nitrogen content, and cell size of Chrysochromulina brevifilum (Prymnesiophyceae). Phycologia 34:128-134

Kawachi M, Inouye I, Maeda O, Chihara M (1991) The haptonema as a food capturing device: observations on Chrysochromulina hirta (Prymnesiophyceae). Phycologia 30:563-573

Kinner NE, Harvey RW, Blakeslee K, Novarino G, Meeker LD (1998) Size-selective predation of groundwater bacteria by nanoflagellates in an organically-contaminated aquifer. Appl Environ Microbiol 64:618-625

Legrand C, Johansson N, Johnsen G, Borsheim KY, Graneli E (2001) Phagotrophy and toxicity variation in the mixotrophic Prymnesium patelliferum (Haptophyceae). Limnol Oceanogr 46:1208-1214

Manton I, Leadbeater BSC (1974) Fine-structural observations on six species of Chrysochromulina from Danish

Editorial responsibility: Fereidoun Rassoulzadegan,

Villefranche-sur-Mer, France marine nanoplankton, including a description of $C$. campanulifera sp. nov. and a preliminary summary of the nanoplankton as a whole. Biol Skr 20:1-26

Moestrup O (1994) Economic aspects: 'blooms', nuisance species, and toxins. In: Green JC, Leadbeater BSC (eds) The haptophyte algae, Spec Vol No. 51. Systematic Association, Clarendon Press, Oxford, p 265-285

Nodwell LM, Price NM (2001) Direct use of inorganic colloidal iron by marine mixotrophic phytoplankton. Limnol Oceanogr 46:765-777

Nygaard K, Tobiesen A (1993) Bacterivory in algae: a survival strategy during nutrient limitation. Limnol Oceanogr 38: $273-279$

Otterstrom CV, Snielsen E (1940) Two cases of extensive mortality in fishes caused by the flagellate Prymnesium parvum. Rep Dan Biol Stn 44:1-24

Parke M, Adams I (1960) The motile (Crystallolithus hyalinus Gaarder and Markali) and non-motile phases in the life history of Coccolithus pelagicus (Wallich) Schiller. J Mar Biol Assoc UK 39:263-274

Parke M, Manton I, Clarke B (1955) Studies on marine flagellates. II. Three new species of Chrysochromulina. J Mar Biol Assoc UK 34:579-609

Parke M, Manton I, Clarke B (1956) Studies on marine flagellates. III. Three further species of Chrysochromulina. J Mar Biol Assoc UK 35:387-414

Round FE, Crawford RM, Mann DG (1990) The diatoms. Biology and morphology of the genera. Cambridge University Press, Cambridge

Thomsen HA, Buck KR, Chavez FP (1994) Haptophytes as components of marine phytoplankton. In: Green JC, Leadbeater BSC (eds) The haptophyte algae, Spec Vol No. 51. Systematic Association, Clarendon Press, Oxford, p 187-208

Tillmann U (1998) Phagotrophy by a plastidic haptophyte, Prymnesium patelliferum. Aquat Microb Ecol 14:155-160

Tillmann U (2003) Kill and eat your predator: a winning strategy of the planktonic flagellate Prymnesium parvum. Aquat Microb Ecol 32:73-84

Von Steinberg C (1980) Notiz zur Phagotrophie einer SpumellaArt (Chrysophyceae) im Walchensee. Schweiz Z Hydrol 42:72-77

Submitted: January 17, 2003; Accepted: July 24, 2003

Proofs received from author(s): September 23, 2003 